Article

\title{
A belief-based parenting behavior model for promoting family's ability to care for children with avoidant restrictive food intake disorder (ARFID) in Indonesia
}

\author{
Yoyok Bekti Prasetyo, ${ }^{1}$ Nursalam Nursalam, ${ }^{2}$ Ika Yuni Widyawati, ${ }^{2}$ Rahmat Hargono, ${ }^{3}$ \\ Ahsan Ahsan, ${ }^{4}$ Kumboyono Kumboyono ${ }^{4}$
}

${ }^{1}$ Community Department, Department of Nursing, Faculty of Health Sciences, University of Muhammadiyah Malang, Kota Malang, Jawa Timur; ${ }^{2}$ Department of Health Sciences, Faculty of Public Health, Airlangga University, Surabaya; ${ }^{3}$ Department of Health Education and Behavioural Sciences, Faculty of Public Health, Airlangga University, Surabaya; ${ }^{4}$ Department of Nursing, Faculty of Medicine, Brawijaya University, Kota Malang, Jawa Timur, Indonesia

\begin{abstract}
Background: Family's ability to care for children with avoidant restrictive food intake disorder (ARFID) is a central indicator in preventing the children from worse nutritional disorders. Environmental factor, child factor, caregiving behavioral systems, and beliefs can improve the family's ability to care for children. The aim of this research was to analyze the effect of environmental factor, child factor, caregiving behavioral systems, and beliefs on the family's ability to care for children with ARFID.

Design and Methods: This cross-sectional research was carried out on 245 families with children suffering from ARFID in Malang Regency, in the working area of the Health Office of Malang Regency. The population of this research was families with children suffering from ARFID within the working area of the Health Office of Malang Regency. The research sample size was computed using the rule of thumb in structural equation modeling (SEM), the sample size used was 245.

Results: Results showed that the family's ability to care for children with ARFID was highly influenced by the caregiver's belief $(t=21.796 ; \beta=0.713)$. Caregiver's belief became a dominant factor in the promotion of the family's ability to care for children with ARFID. A caregiver's belief was influenced by his/her behavior.

Conclusions: It was concluded that the caregiver's belief serves as a primary factor in the promotion of the family's ability to care for children with ARFID. A caregiver's behavior holds a prominent role in influencing his/her belief in providing care for children suffering from ARFID.
\end{abstract}

\section{Introduction}

Nutritional issues in children remain a major problem in developing countries. Low-income countries will be at risk of $65 \%$ under-fives experiencing growth and developmental disor- ders due to undernutrition and over nutrition. ${ }^{1}$ One of the nutritional problems encountered in under-fives is avoidant restrictive food intake disorder (ARFID). ${ }^{2}$ ARFID is a new term illustrating feeding disorders in infants and toddlers with the characteristics refusing eating, poor eating schedule, low eating skills inappropriate to child developmental phase, lack of interest in eating, avoidance based on the sensory characteristics of food (foods appearance, aroma, and flavor), fear arising when eating like dysphagia, and fear of swallowing food. ${ }^{3}$

Children struggling with ARFID will experience disturbances to their growth and development. They will undergo stunting and wasting. ${ }^{4}$ Indonesia is going through fluctuating and upward trends of stunting within the period $2007-2010$. This is as demonstrated by Indonesia's stunting data: $36.8 \%$ in $2007,25.6 \%$ in 2010 , and $37.2 \%$ in $2013 .^{5}$ The problem of difficulty eating in children is affected to a high degree by family factors, especially mother-child dysfunctional interactions, environmental and sociocultural influences, and psychological tension. ${ }^{6}$ Johnson's behavioral system model (JBSM) describes patients, in this case caregivers, as a behavioral system that is composed of complex subsystems: affiliative, dependence, ingestive, eliminative, sexual, aggressive, and achievement. ${ }^{7}$ One of the determinants of the imprinting of good eating behavior by mothers in their children is belief. The belief concept in the health belief model (HBM) can be used to determine mother's belief in taking disease-preventing actions and carrying out health-promoting activities and to shed light on why a mother changes or maintains specific health behaviours. ${ }^{8}$

This study was aimed at analyzing the simultaneous effect of environmental factor, child factor, belief, and mother's behavior system on family's ability to care for children with ARFID. The results of this research will be useful for the fostering of family's ability to provide care for children with ARFID. Improved family's ability to provide care for children with ARFID will prevent nutritional disorders in children like stunting and wasting.

The relationship between factors that influence family's ability to care for children with ARFID and the nutritional status of

Significance for public health

The results of this research will be useful for the fostering of family's ability to provide care for children with ARFID. Improved family's ability to provide care for children with ARFID will prevent nutritional disorders in children like stunting and wasting. 
children with ARFID can be seen in this research's conceptual framework below (Figure 1).

\section{Design}

The research used a cross-sectional design with surveys by structural equation modelling (SEM) to investigate the effects of caregiving behavioral system (CBS) through individual belief (IB) on family's ability (FA) and child nutrition (CN), where CBS served as a mediating factor in the relationships between environmental factor (EF) and IB and between child factor (CF) and IB.

\section{Participants}

The population of this research was families with children suffering from ARFID within the working area of the Health Office of Malang Regency. The research sample size was computed using the rule of thumb in structural equation modelling (SEM), i.e., the number of parameters estimated was multiplied by 5 or 10 . The number of parameters was identified from the indicators and structures. There were 21 indicators, making the total number of indicators estimated $42(21 \times 2=42)$, while the number of structures estimated was 7 . The total number of parameters estimated was 49 $(42+7=49)$, and, thus, the sample size used was $245(5 \times 49=245)$.

\section{Public Health Center (Puskesmas)}

Some puskesmas were selected by the simple random sampling technique by randomly choosing three from five puskesmas in the working area of the Health Office of Malang Regency. The puskesmas selected were Puskesmas Karangploso, Singosari, and Ardimulyo.

\section{Integrated Services Post (Posyandu)}

Some posyandu were selected by the proportionate random sampling technique from three puskesmas of choice. The researchers needed $20 \%$ of the posyandu in each of the operating areas of the puskesmas of choice. Puskesmas Karangploso's area had 71 posyandu, Puskesmas Singosari's area 95 posyandu, and Puskesmas Ardimulyo's area 65 posyandu. Hence, the numbers of posyandu in the operating areas of Puskesmas Karangploso, Puskesmas Singosari, and Puskesmas Ardimulyo were 14, 19, and 13 , respectively. The total number of posyandu enrolled sample was 46 .

\section{Family}

As many as 246 families with children suffering from ARFID were selected by the simple random sampling technique from the 24 posyandu in the operating areas of the three selected puskesmas. The family inclusion criterion was mothers being the main care-

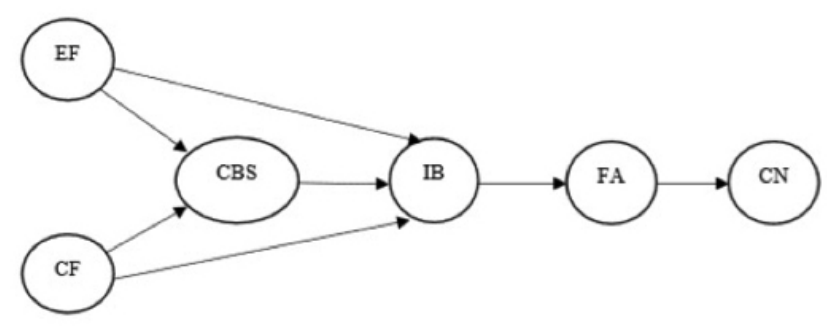

Figure 1. Research conceptual framework. EF, environmental factor; CF, child factor; CBS, caregiving behavioral system; IB, individual belief; FA, family's ability; CN, child nutrition. givers for children with ARFID. The characteristics of children with ARFID used in this research were having ARFID, aged below five years, having no chronic diseases, having no congenital defects in the digestive tract, and avoiding food due to sensory stimuli (food appearance, aroma, and flavour).

\section{Data collection}

\section{Questionnaires}

The data in this research were collected using questionnaires which integrated the parent child interaction model (PCIM), JBSM, and HBM theories. Participants filled out the questionnaires within the agreed upon period. The questionnaires measured the variables researched, namely EF (environmental factor), $\mathrm{CF}$ (child factor), CBS (caregiving behavioural system), IB (individual belief), FA (family's ability), and $\mathrm{CN}$ (child nutrition). The measurement tools are be developed by our self.

\section{Environmental factor questionnaire}

Environmental factor (EF) was measured using a questionnaire consisting of three indicators, namely physical environment (4 items), father closeness ( 7 items), and parents' cooperation (8 items). Scoring was based on a Likert scale anchored by 1 (never) to 5 (always). The maximum and minimum scores were 19 and 95 , respectively.

\section{Child factor questionnaire}

Child factor (CF) was measured using a questionnaire consisting of two indicators, namely temperament and adaptability. The child temperament items were adopted from the Temperament Assessment Scale for Children (8 items), and the child adaptability items were adopted from the Child Behaviour Checklist (16 items). Scoring was based on a Likert scale anchored by 0 (never) to 2 (sometimes). The maximum and minimum score were 0 and 24 , respectively.

\section{Caregiving behavioral system questionnaire}

Caregiving behavioral system (CBS) was measured using a questionnaire consisting of seven indicators, namely attachmentaffiliative (7 items), dependency (6 items), ingestive (13 items), eliminative (3 items), sexual (10 items), achievement (3 items), and aggressive/protective (5 items). Items 3 and 4 in the dependency indicator, items 4-8 and 10-12 in the ingestive indicator, and an item in the eliminative indicator were scored inversely. The sexual indicator items were adopted from the Female Sexual Function Index (FSFI). Scoring was based on a Likert scale anchored by 1 (never) to 5 (always).

\section{Individual belief questionnaire}

Individual belief (IB) was measured using a questionnaire consisting of five indicators, namely perceived susceptibility (4 items), perceived severity (11 items), perceived benefits (10 items), perceived barriers ( 7 items), and self-efficacy ( 7 items). Scoring was based on a Likert scale anchored by 1 (never) to 5 (always).

\section{Family's ability questionnaire}

Family's ability (FA) refers to family's ability to care for children with AFRID. Measurement of this variable was conducted using a questionnaire consisting of two indicators, namely ability to manage eating disorders ( 9 items) and ability in promotive behavior (11 items). Scoring was based on a Likert scale anchored by 1 (never) to 5 (always). 


\section{Child nutrition questionnaire}

Child nutrition $(\mathrm{CN})$ was anthropometrically measured based on WHO's standard of 2005. The indices used included the weightfor-age index (BW/A) (Z-score classification: extremely underweight $=<-3.0 \mathrm{SD}$; underweight $=-3 \mathrm{SD}$ to $<-2.0 \mathrm{SD}$; normal $=$ $2 \mathrm{SD}$ to $+2 \mathrm{SD}$; overweight $=>+2 \mathrm{SD})$ ), the height-for-age index (BH/A) (Z-score classification: extremely stunted $=<-3.0 \mathrm{SD}$; stunted $=-3 \mathrm{SD}$ to $<-2.0 \mathrm{SD}$; normal $=-2 \mathrm{SD}$ to $+2 \mathrm{SD}$; lanky $=>2$ $\mathrm{SD})$, and the weight-for-height $(\mathrm{BW} / \mathrm{BH})(\mathrm{Z}$-score $\mathrm{BW} / \mathrm{BH}$ : extremely wasted $=<-3.0 \mathrm{SD}$; wasted $=-3 \mathrm{SD}$ to $<-2.0 \mathrm{SD}$; normal $=-2 \mathrm{SD}$ to $2 \mathrm{SD}$; obese $=>2 \mathrm{SD}$ ).

\section{Questionnaires validity and reliability testing}

Validity and reliability tests of the five questionnaires were performed on 25 mother participants with children who struggled with ARFID. The validity for EF, CF, CBS, IB, and FA were reported as $0.60,0.54,0.58,0.67$, and 0.68 , respectively. The Cronbach's alpha was used to assess reliability. The Cronbach's alpha coefficients for $\mathrm{EF}, \mathrm{CF}, \mathrm{CBS}, \mathrm{IB}$, and FA ware reported as $0.61,0.80,0.69,0.75$, and 0.86 , respectively.

\section{Data collection procedure}

The study has conducted in the early week of August 2018 until the end of February 2019. Questionnaires were distributed by the research staff to every mother of child with ARFID at her home. The questionnaires filled out in complete by the mothers were returned to the research staff, who later submitted the filledout questionnaires to the researchers. The whole data collection process took two months to complete.

\section{Data analysis}

The model testing in this research used the partial least squares-structural equation modelling (PLS-SEM), which is a regression technique that explores the linear relationship between some independent variables and one or more dependent variables. ${ }^{9}$ Given that the primary assumption for the SEM data analysis was that the data were normally distributed, a Kolmogorov-Smirnov test was performed (Table 1). The data analysis used the SPSS v. 22 software to describe the demographic variable. The mean and standard deviation values of the independent variables were analyzed using the PLS v. 2 software.

\section{Results}

\section{Demographic characteristics of mother participants with children suffering from ARFID}

The average age of the mothers was $30.2 \pm 6.1$ years. Most of the mothers were senior high school graduates (36.3\%) and were unemployed (77.6\%). A larger portion of the mothers came from families with monthly income of Rp 1-2 million (51.4\%) and families with only one child (42.4\%). The average age of the children was $2.1 \pm 1.1$ years. There were more female than male children $(55.1 \%$ vs. $44.9 \%)$. The majority of the children were of normal nutritional status based on the BW/A (8.4\%), BH/A (60.8\%), and $\mathrm{BW} / \mathrm{BH}(76.7 \%)$ indices, although nutritional disorders in the form of stunting and wasting were also identified (35.9\% and $12.3 \%$, respectively) (Table 2).

\section{Measurement model}

For data analysis using the SEM-PLS, the measurement and structural model fit should be first examined to ensure their utility. The measurement model shows how manifest or observed variables represent latent variables to measure. The structural model is used to analyze the path between exogenous latent constructs (independent variables) and endogenous ones (dependent variables). ${ }^{10}$

Table 1. Kolmogorov-Smirnov test for research variables.

\begin{tabular}{lcc} 
Variables & Test statistic & p-value \\
EF & 0.036 & 0.200 \\
CF & 0.052 & 0.200 \\
\hline CBS & 0.057 & 0.060 \\
IB & 0.034 & 0.200 \\
\hline FA & 0.030 & 0.200 \\
CN & 0.041 & 0.200 \\
\hline
\end{tabular}

Table 2. Demographic characteristics of the participants.

\begin{tabular}{|c|c|c|}
\hline Demographic characteristics & n & $\%$ \\
\hline $\begin{array}{l}\text { Mothers' ages (years) } \\
\quad 17-25 \\
26-35 \\
36-45\end{array}$ & $\begin{array}{c}61 \\
139 \\
45\end{array}$ & $\begin{array}{l}24.9 \\
56.7 \\
18.4\end{array}$ \\
\hline $\begin{array}{l}\text { Mothers' education } \\
\text { Primary education } \\
\text { Lower secondary education } \\
\text { Upper secondary education } \\
\text { Tertiary education }\end{array}$ & $\begin{array}{l}50 \\
75 \\
89 \\
31\end{array}$ & $\begin{array}{l}20.4 \\
30.6 \\
36.3 \\
12.7\end{array}$ \\
\hline $\begin{array}{l}\text { Mothers' occupational statuses } \\
\text { Employed } \\
\text { Unemployed }\end{array}$ & $\begin{array}{c}55 \\
190\end{array}$ & $\begin{array}{l}22.4 \\
77.6\end{array}$ \\
\hline $\begin{array}{l}\text { Family income } \\
\text { >Rp } 2 \text { million } \\
\text { Rp 1-2 million } \\
\text { <Rp1 million }\end{array}$ & $\begin{array}{c}63 \\
126 \\
56\end{array}$ & $\begin{array}{l}25.7 \\
51.4 \\
22.9\end{array}$ \\
\hline $\begin{array}{c}\text { Number of children } \\
1 \\
2 \\
3 \\
4 \\
5\end{array}$ & $\begin{array}{c}104 \\
97 \\
36 \\
7 \\
1\end{array}$ & $\begin{array}{l}42.4 \\
39.6 \\
14.7 \\
2.9 \\
0.4\end{array}$ \\
\hline $\begin{array}{l}\text { Children's ages (years) } \\
\quad \leq 3 \\
\quad>3-5\end{array}$ & $\begin{array}{c}177 \\
68\end{array}$ & $\begin{array}{l}72.2 \\
27.8\end{array}$ \\
\hline $\begin{array}{l}\text { Children's genders } \\
\text { Male } \\
\text { Female }\end{array}$ & $\begin{array}{l}110 \\
135\end{array}$ & $\begin{array}{l}44.9 \\
55.1\end{array}$ \\
\hline $\begin{array}{l}\text { Body weight for age index (BW/A) } \\
\text { Overweight } \\
\text { Normal weight } \\
\text { Underweight } \\
\text { Extremely underweight }\end{array}$ & $\begin{array}{c}2 \\
197 \\
39 \\
7\end{array}$ & $\begin{array}{c}0.8 \\
80.4 \\
15.9 \\
2.9\end{array}$ \\
\hline $\begin{array}{l}\text { Body height for age index (BH/A) } \\
\text { Lanky } \\
\text { Normal } \\
\text { Stunted } \\
\text { Extremely stunted }\end{array}$ & $\begin{array}{c}8 \\
149 \\
38 \\
50\end{array}$ & $\begin{array}{l}3.3 \\
60.8 \\
15.5 \\
20.4\end{array}$ \\
\hline $\begin{array}{l}\text { Body weight for body height index } \\
\text { Obese } \\
\text { Normal } \\
\text { Wasted } \\
\text { Extremely wasted }\end{array}$ & $\begin{array}{l}\text { H) } \\
27 \\
188 \\
23 \\
7\end{array}$ & $\begin{array}{c}11 \\
76.7 \\
9.4 \\
2.9\end{array}$ \\
\hline
\end{tabular}




\section{Indicator reliability}

Indicator reliability reflects which indicators are fit in a latent construct. Reliability was calculated using factor loading by drawing correlations between constructs and indicators. Based on the rule of thumb, the factor loading for research of exploratory nature is anything between 0.4 and 0.7 . In this research, the factor loading used was equal to or higher than 0.5 . Indicators scoring below 0.5 would be dropped from the modelling. The reliability scores of the indicators forming this research's constructs can be seen in Table 3 .

\section{Construct reliability}

For measuring the construct reliability, Cronbach's alpha and composite reliability coefficients were used. Composite reliability coefficients beyond 0.7 indicate internal consistency within a measurement model. For EC, CF, CBS, IB, FA, and CN, the composite reliability coefficients were $0.917,1.000,0.794,0.850$, 0.937 , and 0.794 , respectively. Therefore, the reliability of all variables was confirmed (Table 4).

\section{Convergent validity}

Convergent validity is a measure of the model fit. Average variance extracted (AVE) is used to measure the amount of the variance captured by constructs in comparison to the variance caused by measurement errors. AVE values should at least be 0.5 . These values describe adequate convergent validity, which means that one latent variable is able to explain more than half of the variance of indicators in average. In this research, the AVE of EF, CF, CBS, IB, FA, and CN were $0.847,1.000,0.437,0.739,0.882$, and 0.614 , respectively (Table 2 ).

\section{Discriminant validity}

Discriminant validity concerns with the principle that measures (manifest variables) of different constructs should have no significant correlation. To test the discriminant validity, the square root of AVE for every construct is compared with the correlation coefficient between construct in a model. ${ }^{10}$ The results of the discriminant validity testing in this research can be seen in Table 4.

\section{Structural model}

In the present study, to see the structural model fit, significant coefficients ( $t$-value), coefficients of determination or $\mathrm{R}^{2}$, crossvalidated redundancy measure or $\mathrm{Q}^{2}$, effect size or $\mathrm{F}^{2}$, and goodness of fit or GOF were used. ${ }^{10}$

\section{Significant coefficients ( $t$-value)}

The basic criteria used to measure the relationship between constructs were significant coefficients ( $Z$ or $t$-value). The value used as a reference was a T-table value (1.96). An exogenous factor will be declared as influencing an endogenous factor if the T-statistics is higher than the T-table 1.96 at error tolerance $(\alpha)$ of $5 \%$

Table 3. Factor loading for the measurement model.

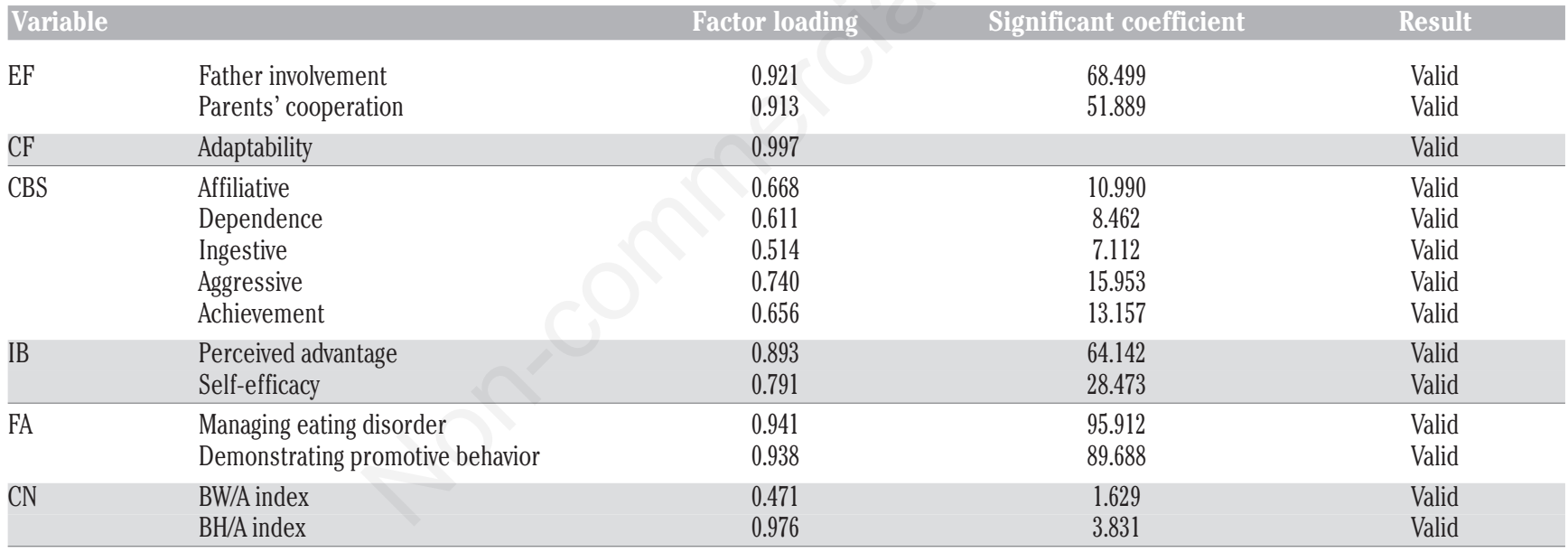

Table 4. Indicators of measurement and the structure model.

\begin{tabular}{|c|c|c|c|c|c|c|c|c|c|c|}
\hline \multirow[t]{2}{*}{ Variable } & \multirow{2}{*}{$\begin{array}{c}\text { Average } \\
\text { Variance } \\
\text { Extracted } \\
\text { (AVE) }\end{array}$} & \multirow{2}{*}{$\begin{array}{c}\text { Cronbach's } \\
\text { Alpha }\end{array}$} & \multirow{2}{*}{$\begin{array}{c}\text { Composite } \\
\text { Reliability } \\
\text { (CR) }\end{array}$} & \multirow[t]{2}{*}{$\mathbf{R}^{2}$} & \multicolumn{6}{|c|}{ Correlation of constructs } \\
\hline & & & & & (1) & (2) & (3) & (4) & (5) & (6) \\
\hline $\mathrm{EF}(1)$ & 0.847 & 0.820 & 0.917 & & 0.920 & & & & & \\
\hline $\mathrm{CF}(2)$ & 1.000 & 1.000 & 1.000 & & -0.210 & 1 & & & & \\
\hline CBS (3) & 0.437 & 0.676 & 0.794 & 0.271 & 0.520 & -0.128 & 0.661 & & & \\
\hline IB (4) & 0.739 & 0.650 & 0.850 & 0.322 & 0.296 & 0.024 & 0.559 & 0.860 & & \\
\hline FA (5) & 0.882 & 0.866 & 0.937 & 0.509 & 0.409 & -0.029 & 0.555 & 0.713 & 0.939 & \\
\hline $\mathrm{CN}(6)$ & 0.614 & 0.467 & 0.747 & 0.016 & 0.140 & -0.089 & 0.056 & 0.077 & 0.127 & 0.783 \\
\hline
\end{tabular}


and 1.65 at error tolerance $(\alpha)$ of $10 \%$. The significance test result of the structural model (inner model) can be seen in Table 5 and Figure 2.

\section{Coefficient of determination $\left(R^{2}\right)$}

$\mathrm{R}$-squared $\left(\mathrm{R}^{2}\right)$ as the predictive power of endogenous constructs stands anywhere between 0 and 1 . An R-squared value of 0.67 is considered strong, 0.33 moderate, and 0.19 weak. ${ }^{10}$ From this study it was found that CBS was able to predict IB and FA moderately ( $\mathrm{R}^{2}$ of 0.322 and 0.509 , respectively). CBS was also able to predict $\mathrm{CN}$ weakly with $\mathrm{R}^{2}=0.016$. These values suggest that the model was fit (Table 5, Figure 3).

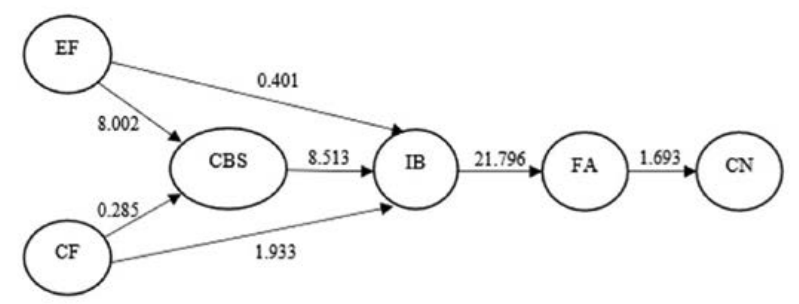

Figure 2. T-value for an estimate path coefficient meaningful in model. EF, environmental factor; CF, child factor; CBS, caregiving behavioral system; IB, individual belief; FA, family's ability; $\mathrm{CN}$, child nutrition.

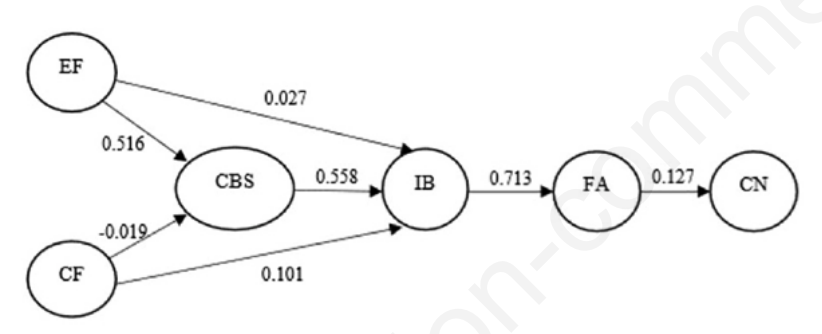

Figure 3. Structural research model in the standard estimation mode. EF, environmental factor; CF, child factor; CBS, caregiving behavioral system; IB, individual belief; FA, family's ability; CN, child nutrition.

Table 5. Result for the study paths.

\begin{tabular}{lccc} 
Paths & B & t-value & Result \\
EF to CBS & 0.516 & $8.002^{*}$ & Significant \\
CF to CBS & -0.019 & $0.285^{*}$ & Non significant \\
\hline CBS to IB & 0.558 & $8.513^{*}$ & Significant \\
EF to IB & 0.027 & $0.401^{*}$ & Non significant \\
\hline CF to IB & 0.101 & $1.933^{\circ}$ & Significant \\
IB to FA & 0.713 & $21.796^{*}$ & Significant \\
\hline FA to CN & 0.127 & $1.693^{\circ}$ & Significant \\
\hline
\end{tabular}

${ }^{*} \mathrm{p} \leq 0.05 ;{ }^{\circ} \mathrm{p} \leq 0.10$.

\section{Cross-validated redundancy measure (CV-Red)}

The $\mathrm{Q}^{2}$ or CV-Red is used to see the predictive relevance of the research model. A $\mathrm{Q}^{2}$ value greater than zero means that the model has predictive relevance. ${ }^{10}$ To calculate the $\mathrm{Q}^{2}$ in this research, the following formula was used.

$\mathrm{Q}^{2}=1-\left(1-\mathrm{R} 1^{2}\right)\left(1-\mathrm{R} 2^{2}\right) \ldots \ldots\left(1-\mathrm{Rp}^{2}\right) \ldots$
$\mathrm{Q}^{2}=1-(1-0.509)(1-0.322)(1-0.016)(1-0.271)$
$\mathrm{Q}^{2}=0.761$

\section{Effect size $\left(\mathbf{F}^{2}\right)$}

$\mathrm{F}^{2}$ is used to determine the strength of the relationship between structural models and to indicate the predictive relation between exogenous and endogenous constructs. $\mathrm{F}^{2}$ values of $0.02,0.15$, and 0.35 suggest low, moderate, and high effects, respectively. The effects of EF on CBS in this research had a value of 0.516 (high), CBS on IB 0.558 (high), IB on FA 0.713 (high), and FA on CN 0.127 (moderate) (Figure 3).

\section{Goodness of fit (GoF)}

GoF is used to evaluate the measurement and structural models, and it provides simple measurement of all models' prediction. ${ }^{10} \mathrm{GoF}$ indices of $0.01,0.25$, and 0.35 describe low, moderate, and strong fit, respectively. To calculate the GoF index in this research, the following formula was used:

$$
\sqrt{\text { Ave } R 2 x \text { (Ave of communalities) }}
$$

Calculated using the formula above, the GoF index was found to be 0.458 . This shows that the model fit was strong.

\section{Hypothesis testing}

Significant coefficient and t-value were used to determine the between-variable relationship as shown in Table 4 and Figures 2 and 3. EF significantly influenced CBS $(t=8.002 ; \beta=0.516), \mathrm{CF}$ did not significantly influence CBS $(\mathrm{t}=0.285 ; \beta=-0.019)$, CBS significantly influenced IB $(\mathrm{t}=8.513 ; \beta=0.558)$, EF did not significantly influence IB $(\mathrm{t}=0.401 ; \beta=0.027)$, CF significantly influenced IB $(\mathrm{t}=1.933 ; \beta=0.101)$, IB significantly influenced FA $(\mathrm{t}=21.796 ; \beta=0.713)$, and FA significantly influenced $\mathrm{CN}(\mathrm{t}=$ $1.693 ; \beta=0.127)$.

\section{Discussion}

The present research yielded a number of findings. First, environmental factor had a positive effect on caregiving behavioral system, and destructive environmental factor had a negative one. Too strong environmental factor influence will be detrimental to behavior system and threaten one's stability. When the environment is stable, an individual will be enabled to develop good behavior. The way an individual behaves is influenced by his/her interactions with someone else in his/her environment. One's behavioral characteristics when seeking health information will be determined by his/her desire to control his/her health and by 
his/her awareness of environmental factor. ${ }^{11}$ His/her success in health education will also depend largely on environmental factor. ${ }^{12}$ Based on the sociological model, parent's attitude, beliefs, norms, and behavior are formed out of social and environmental factors in a home setting. The environment has a role in influencing one's decisions on which actions to be taken. ${ }^{13}$ Differences in social environments and home situations contributes to differences in eating behavior and food intake. The environment can be a trigger of the high food intake and the high responsive behavior of mothers to their children. ${ }^{14}$

Second, child factor influenced caregiver's belief. The reason is that poor child conditions like health problems, child anxiety, and difficulties adapting can influence parent's belief. Parent's belief is linked to children's level of anxiety ${ }^{15}$ and health problem prognosis. It was reported by a separate study that parent's belief is affected by the severity of children's conditions. Parent's belief also has a link to children's adaptability. ${ }^{16}$ The Barriers to Treatment Model theory states that child problems will influence stress levels and set impediments to parent's actions, for example impediments to participation and perception on the actions needed to care for children. ${ }^{17}$

Third, caregiving behavioral system influenced belief. Caregiving behavioral system refers to mothers' behavioral and personal characteristics that will shape their beliefs. This reflects the five foundational dimensions explained in the fife-factor model (FFM): openness to experience (fantasies, aesthetics, feelings, actions, ideas, values), conscientiousness (competencies, order, obedience, efforts for achievement, self-discipline, freedom), extraversion (warmth, friendliness, firmness, activities, pleasure seeking, positive emotions), agreeableness (belief, straightforwardness, altruism, submissiveness, politeness, modesty, gentle mind), and neuroticism (emotional stability, anxiety, hostility, depression, self-consciousness, impulsiveness, vulnerability). ${ }^{18}$ There are two factors that explain health behavior in HBM, namely perception on health threats and perception on specific behavior to reduce and eliminate threats. Perception on threats is strongly influenced by personal belief about vulnerability. Previous research shows that mother's behavior in eating activities has an effect on child's eating pattern. Parent's feeding practices include activities related to provision and socialization of food (e.g., teaching appropriate eating manners and habits). This is used by caregivers to manage children's food intake in terms of what, when, and how much children should eat. ${ }^{19}$

Fourth, strengthened caregiver's belief would improve family's ability to care for children with ARFID. This is in line with the health belief model (HBM) theory, stating that strong individual belief determines which actions to take. HBM is a socio-psychological model that describes and predicts health behaviors with a focus on individual attitudes and beliefs. According to this model, an individual will tend to engage health behavior more if he/she is feeling vulnerable to certain health problems. He/she adopts health behavior when they feel that health behavior benefits are more favorable than the bother of adopting protective behaviour. ${ }^{20}$ Motivation for protection results from perceived threats and the urge to avoid potential negative outcomes.

Fifth, individual belief about health problems and preventive behavior played a key role in facilitating or inhibiting health-promoting behavior. Weak belief contributes to failure to find health service due to inadequate perceived control over health. Another research study showed that mother's belief is related to feeding patterns and children's body weight status. ${ }^{21}$ Belief of good category and the highest value is determined by the indicator self-efficacy. This suggests that self-efficacy is a pivotal part of mother's belief formation in providing care for children with ARFID. It was proven by an earlier study that mothers' low self-efficacy is correlated with their low ability to deal with difficult eating disorders in children. Mothers with low self-efficacy will suffer from depression. This will subsequently affect the optimal child feeding practice.

Sixth, belief also influenced family's ability to care for children with ARFID. The reason is that belief serves as a predictor for taking protective actions against the threats of health problems, including ARFID. Besides, belief also dictates one's disease-preventing actions and health-promoting activities. This explains why an individual changes or maintains specific health behaviors and why he/she fails to participate in activities that are aimed to detect and prevent diseases and predict his/her actions in prevention, screening, and control over ill conditions.

Seventh, improved caregiver's ability to care for children with ARFID, in this case the ability to manage children's eating schedule, would also improve children's nutritional status. Nutritional program support in family and at school can improve children's diet and nutritional status. ${ }^{22}$ Parents' concern with children's body weight status (overweight or underweight) is predicted to be related to negative/sub-nutritional feeding. ${ }^{23}$

Lastly, environmental factor was found not to directly affect caregiver's belief as caregiver's belief is influenced by other factors like age, gender, ethnicity, personality, socioeconomic status, and knowledge. This, too, is in line with the HBM theory, which states that individual belief is affected by perception. Individual perception is comprised of demographic factor and psychological characters. The demographic factor affecting individual health belief model is socioeconomic class. Individuals of lower-middle class lack the knowledge of disease risk factors, while knowledge serves as an essential determinant of one's belief. Poor knowledge will cause an individual not to be vulnerable to disturbances. ${ }^{24}$

\section{Conclusions}

Based on the research results, it can be concluded that caregiver's belief is a key factor in the promotion of family's ability to care for children with ARFID. In the provision of care for children with ARFID, caregivers' belief is highly influenced by their behavior. Caregiver's affiliative, dependent, ingestive, aggressive, and achievement behaviors are primary indicators that shape the parenting behavior that mothers as caregivers will demonstrate when caring for their children. Meanwhile, this caregiving behavioral system is strongly affected by environmental factors, namely husband involvement and parents' cooperation. A further study that explores father's involvement in dealing with children's difficulty eating will be necessary. The results of this research offer an option of intervention for community nurses in the effort of improving child-nutrition-and-health-based services. To date, the focus of intervention has been on nutritional disorders. With these research results, however, the focus of intervention can be shifted to promotive and preventive efforts before the actual nutritional disorders should occur. 
Correspondence: Kumboyono Kumboyono, School of Nursing, Faculty of Medicine, Brawijaya University, Kota Malang, Jawa Timur, Indonesia.

Tel. +62.81805004106 - Fax: +62.0341564755

E-mail: abu_hilmi.fk@ub.ac.id / publikasikoe@gmail.com

Key words: Belief-based parenting behavior model; avoidant restrictive food intake disorder; child health; family; Indonesia.

Contributions: YBP, NN, RH, AA, KK, study concept; YBP, data curation; KK, formal analysis; YBP, NN, KK, investigation; YBP, NN, RH, AA, methodology, resources; IYW, software; NN, supervision; RH, AA, validation; YBP, KK, manuscript original draft, review and editing. All the authors have read and approved the final version of the manuscript and agreed to be accountable for all aspects of the work.

Conflict of interest: The authors declare no conflict of interest.

Funding: The research was funded by Faculty of Health Sciences, University of Muhammadiyah Malang, Indonesia.

Acknowledgements: The authors would like express gratitude to the Head of the Health Office of Malang Regency, who have permitted this research, and all the participants involved.

Ethical approval: This study was conducted according to the guidelines laid down in the Declaration of Helsinki and all procedures involving research study participants were approved by the Health Research Ethics Commission of the Faculty of Public Health, Universitas Airlangga (Approval No. 333-KEPK)

Availability of data and materials: The data and materials underlying this manuscript will be shared on an application to the first and corresponding author.

Received for publication: 13 December 2020

Accepted for publication: 12 January 2021.

o Copyright: the Author(s), 2021

Licensee PAGEPress, Italy

Journal of Public Health Research 2021;10:1964

doi:10.4081/jphr.2021.1964

This work is licensed under a Creative Commons Attribution NonCommercial 4.0 License (CC BY-NC 4.0).

\section{References}

1. Skovgaard Væver M, Smith-Nielsen J, dan Lange T. Copenhagen infant mental health project: Study protocol for a randomized controlled trial comparing Circle of Security-Parenting and care as usual as interventions targeting infant mental health risks. BMC Psychol 2016;4:57.

2. Delisle H, Shrimpton R, Blaney S, et al. Capacity-building for a strong public health nutrition workforce in low- resource countries. Bull World Health Organ 2017;95:385-38.

3. Hay P, Girosi F, dan Mond J. Prevalence and sociodemographic correlates of DSM-5 eating disorders in the Australian population. J Eat Disord 2015;3:19.

4. Nicely TA, Lane-Loney S, Masciulli E, et al. Prevalence and characteristics of avoidant/restrictive food intake disorder in a cohort of young patients in day treatment for eating disorders. J Eat Disord 2014;2:21.

5. Segovia MJG. Psychological and psychological impairment in preschoolers with selective eating. Acta Pediatr Esp 2015;73:240.

6. Republic of Indonesia Ministry for People's Welfare. Policy Framework for the National Movement for the Acceleration of Nutrition Improvement in the Framework of the First Thousand Days of Life. 2013. [in Indonesian]. Available from: https://www.bappenas.go.id/files/7713/8848/0483/KERANGKA_KEBIJAKAN_-_10_Sept_2013.pdf
7. Squires C, Lalanne C, Murday N, et al. The influence of eating disorders on mothers' sensitivity and adaptation during feeding: a longitudinal observational study. BMC Pregnancy Childbirth 2015; $14: 274$

8. Fawcett J. Applying conceptual models of nursing: quality improvement, research, and practice. New York: Springer. 2017.

9. Azman AHN. Structural Equation Modelling (SEM): Confirmatory Factor Analysis (CFA). Researchgate 2017. doi: 10.13140/RG.2.2.25615.38565

10. Garson GD. Partial least squares: regression and structural equation models. Asheboro: Statistical Associates Publishers. 2016. Available from: www.statisticalassociates.com

11. Poortaghi S, Raiesifar A, Bozorgzad P, et al. Evolutionary concept analysis of health seeking behaviour in nursing: a systematic review. BMC Health Serv Res 2015;5:523.

12. Murimi MW, Kanyi M, Mupfudze T, et al. Factors influencing efficacy of nutrition education interventions: A systematic review. J Nutr Educ Behav 2017;49:142-65.e1.

13. Bowen DJ, Quintiliani LM, Bhosrekar SG, et al. Changing the housing environment to reduce obesity in public housing residents: a cluster randomized trial. BMC Public Health 2018;18:883.

14. Westenhoefer J, von Katzler R, Jensen H, et al. Cultural differences in food and shape related attitudes and eating behaviour are associated with differences of Body Mass Index in the same food environment: cross- sectional results from the Seafarer Nutrition Study of Kiribati and European seafarers on. BMC Obes 2018;5:1.

15. Francis SMS, Tone EB, Caporino NE, et al. Cognitive predictors of parental rescue behaviour and malleability of behaviour using a brief psychoeducation intervention. Child Psychiatry Hum Dev 2019;50:321-31.

16. Teng YPT, Kuo LTW, dan Zhou Q. Maternal employment and family socioeconomic status: unique relations to maternal stress, parenting beliefs, and preschoolers' adjustment in Taiwanese families. J Child Fam Stud 2018;27:3506-19.

17. Pereira AI, dan Barros L. Parental cognitions and motivation to engage in psychological interventions: a systematic review. Child Psychiatry Hum Dev 2019;50:347-61.

18. Skot L, Nielsen JB, dan Leppin A. Who perceives a higher personal risk of developing type 2 diabetes ? A cross- sectional study on associations between personality traits, health-related behaviours and perceptions of susceptibility among university students in Denmark. BMC Public Health 2018;18:972.

19. Walton K, Kuczynski L, Haycraft E, et al. Time to re-think picky eating?: a relational approach to understanding picky eating. Int $\mathrm{J}$ Behav Nutr Phys Act 2017;14:62.

20. Stole HS, Tove L, Nilsen N, Joranger P. Beliefs, attitudes and perceptions to sun-tanning behaviour in the Norwegian population: a cross-sectional study using the health belief model. BMC Public Health 2019;19:206.

21. Greaney ML, Machado MMT, Hasselman MH, et al. Sociocultural and environmental influences on Brazilian immigrant mothers' beliefs and practices related to child feeding and weight status. Matern Child Health J 2016;21:1085-94.

22. Black AP, D'Onise K, McDermott R, et al. How effective are family-based and institutional nutrition interventions in improving children's diet and health? A systematic review. BMC Public Health 2017; 17:818.

23. Warkentin S, Mais LA, Latorre MDRDDO, Carnell S, De Aguiar Carrazedotaddei JA. Relationships between parent feeding behaviors and parent and child characteristics in Brazilian preschoolers: A cross-sectional study. BMC Public Health 2018;18:704.

24. Putri D. Kajian Health Belief Model. 2015. Available from: http://digilib.uinsby.ac.id/13200/5/Bab 2.pdf 